\title{
Effect of façade impregnation on feasibility of capillary active thermal internal insulation for a historic dormitory - A hygrothermal simulation study
}

\author{
Finken, Gholam Reza; Bjarløv, Søren Peter; Peuhkuri, Ruut Hannele
}

Published in:

Construction and Building Materials

Link to article, DOI:

10.1016/j.conbuildmat.2016.03.019

Publication date:

2016

Document Version

Peer reviewed version

Link back to DTU Orbit

Citation (APA):

Finken, G. R., Bjarløv, S. P., \& Peuhkuri, R. H. (2016). Effect of façade impregnation on feasibility of capillary active thermal internal insulation for a historic dormitory - A hygrothermal simulation study. Construction and Building Materials, 113, 202-214. https://doi.org/10.1016/j.conbuildmat.2016.03.019

\section{General rights}

Copyright and moral rights for the publications made accessible in the public portal are retained by the authors and/or other copyright owners and it is a condition of accessing publications that users recognise and abide by the legal requirements associated with these rights.

- Users may download and print one copy of any publication from the public portal for the purpose of private study or research.

- You may not further distribute the material or use it for any profit-making activity or commercial gain

- You may freely distribute the URL identifying the publication in the public portal 
Effect of Façade Impregnation on Feasibility of

\section{A Hygrothermal Simulation Study}

8

9 Finken, Gholam Reza (MSc) ${ }^{1,2}$; Bjarløv, Søren Peter (Associate Professor) ${ }^{2}$; Peuhkuri, 10 Ruut Hannele (PhD, Associate Professor) ${ }^{1,2}$

Affiliations:

${ }^{1}$ Danish Building Research Institute, Aalborg University, Copenhagen, Denmark

${ }^{2}$ Department of Civil Engineering, Building Physics and Services, Technical University of 15 Denmark, Lyngby, Denmark 


\section{Abstract}

2 Internal insulation of external walls is known to create moisture performance challenges due to

3 increased moisture levels and condensation risk on the cold side of the insulation. Capillary

4 active/hydrophilic insulations have been introduced to solve these moisture problems, since they

5 are able to transport liquid moisture to the inner surface and enable it to dry. Experience with this

6 insulation type is rare in Denmark. In hygrothermal 1D computer simulations, several more or less

7 capillary active insulation systems (AAC, calcium silicate, IQ-Therm) in various thicknesses (30 -

$8150 \mathrm{~mm}$ ) have been tested for their hygrothermal performance. The original construction was a

$9228 \mathrm{~mm}$ solid brick masonry wall in a Copenhagen historic dormitory. All simulated systems

10 showed critical relative humidity values above $80 \%$ and high risk of mould growth behind the

11 insulation and some also on the interior surface. A moisture-safe construction was only achieved

12 when exterior façade impregnation shielding against driving rain was added. The best system

13 showed acceptable relative humidity values both behind the insulation and on the interior surface,

14 a significant increase in minimum temperature on the interior surface, and a reduction of heat loss

15 through the external wall by $85 \%$. The solely application of impregnation also resulted in a moisture safe solution with significant improvements in all parameters and heat loss reduction by $45 \%$. The main conclusion is that capillary active insulation may not be feasible on solid bare masonry walls without additional driving rain protecting especially in case of multi-storey buildings with thin walls in high precipitation areas. impregnation, energy savings 


\section{1. Introduction}

2 Since buildings account for around $40 \%$ of the total energy consumption [1], there is a huge

3 potential for a $\mathrm{CO}_{2}$ reduction through energy efficiency retrofit of buildings, where a better

4 insulation of the external walls is one of the most obvious actions. Although external insulation

5 has been proven to be the safest and most effective kind of insulation, this is often not feasible for

6 historic buildings, where an alteration of the façade is not an option, and only internal insulation is

7 possible [2]. Internal insulation has, however, in several cases led to mould problems due to a

8 higher water content as it reduces the heat flow from inside to outside of the external wall

9 thereby creating a higher temperature gradient [2]. To avoid condensation and trapping of water within the structure in cold winter months, vapour diffusion barriers (VDB) have been

11 recommended to disable vapour diffusion from inside to outside [3]. But they need a very accurate fit in order to obtain vapour and airtightness and one can easily break them by normal activities like installing cable inlets, nails etc. thereby creating small holes, which make the VDB ineffective. In addition, the VDB also prevents all inward drying leading potentially to further moisture problems. Therefore, so called smart vapour retarders with a higher permeability for high relative humidities have been developed. These can be used in some cases instead of a VDB without increasing the risk of moisture accumulation behind the membrane [4].

During the last two decades, another concept to solve the problem with interstitial condensation within internally insulated external walls has been developed, tested and applied in some retrofit projects. Instead of trying to avoid condensation, a capillary active porous insulation materials is $[2,7]$. 
1 While the vapour diffusion resistance of VDB should be high enough to avoid condensation problems within the wall, the principle of the capillary active insulation is the opposite, since the wall is not especially tight for diffusion of moisture from the room side. The capillary activity allows the transport and drying out of the possibly occurring condensate, though this condensation is also due to the vapour open character of the insulation material. Capillary active insulation products are normally inorganic like e.g. calcium silicate (CaSi), autoclaved aerated concrete $(A A C)$ or other materials with properties ensuring a high level of hygroscopicity and capillarity e.g. thin mortar channels in PUR-foam based IQ-Therm. However, in recent years, researchers also investigated biodegradable (biotic) insulation materials like for example sheep wool [8], hemp, jute and flax [9]. These ecologically sustainable materials have some relevant hygroscopic properties and are to a certain extent capillary active. They seem to be a promising alternative, but more research is still needed to define their usability.

Nevertheless, while especially the manufacturers promote the capillary active insulation material as the ideal solution for post-insulation of exterior walls in situations where external insulation is not possible, only a few examples in the literature exist that support their feasibility. Especially Häupl and colleagues investigated capillary active inside insulation in historical masonry building façades of e.g. museums and residential buildings mainly in Germany with good results in terms of hygrothermal behaviour [10,11]. Both in the case of The Rijksmuseum Amsterdam and a Founding Year house in Talstrasse in Dresden (Germany), relatively thin CaSi insulation system were applied to relatively thick walls. Thus, the walls of Founding Year house in Talstrasse, Dresden, consisting of $435 \mathrm{~mm}$ masonry and $150 \mathrm{~mm}$ sandstone were insulated with $30 \mathrm{~mm}$ CaSi and the walls of The Rijksmuseum Amsterdam, consisting of $600 \mathrm{~mm}$ brick (480 mm historical brick $+120 \mathrm{~mm}$ clinker) were insulated with a similar thin CaSi insulation. In these cases, the capillary active insulation was 
1 capable of keeping the wall below critical moisture levels with the given moisture load from both driving rain load and interstitial condensation.

3 In contrast, others have pointed to the possible risks and disadvantages of capillary active

4 insulation, since the feasibility seems to depend on several factors as for example the driving rain

5 load, thickness of wall and the moisture capacity i.e. the hygric performance of the material in

6 question. Vereecken \& Roels showed both in an experimental X-ray study [12] and in numerical

7 calculations [13] that walls with capillary active insulation can store much more moisture than

8 walls with VDB. Therefore, it is recommended and needed to analyse the feasibility of the

9 insulation for each case in question.

10 Although this concept has been developed, tested and used for several years mainly in Germany;

11 the feasibility of capillary insulation materials has apparently not been used and discussed much in

12 Denmark or included in the building regulations where the message still is that VDB's are mandatory when internal insulation is applied. It is questionable whether such insulation can be applied without moisture risk when the situation is less favourable, e.g. where the brick walls are thin, as is the case in many Danish historic buildings, e.g. at the upper floors, where the thickness of the external masonry wall is decreasing and especially under windows, where the thickness as a rule is only one- brick, i.e. $228 \mathrm{~mm}$ (1 Danish brick $=228 \times 108 \times 54 \mathrm{~mm}$ ). A thinner wall results in a higher condensation risk and a higher moisture load due to the driving rain in a high precipitation area like in Denmark.

Independently of the material used for internal insulation, adding internal insulation changes the building physical behaviour of the wall. Thus, it leads in any case to a higher moisture level due to a reduction of the drying capacity of the wall. That is why historical buildings that have proven to 
1 withstand the weather for many, many years may get a moisture problem when internally insulated. In contrast to an exterior insulation system which also serves as an effective rain

3 protection for the external wall, the application of insulation layers on the inside of a building does not affect the water absorption of the facade. However, driving rain load can be even more critical

5 for the moisture balance of the façade than the effect of interstitial condensation due to the high amount of precipitation that can be uptaken via capillary suction. It is estimated that up to $70 \%$ of

7 the rainwater can be absorbed by a porous wall [14]; the higher the capillary activity of the material, the more water can penetrate into the wall. Thus, especially historic masonry facades made of porous unplastered brick are greatly exposed.

As showed by e.g. Künzel [15], the moisture performance of a masonry wall in case of internal insulation can be improved by adding water-repellent façade impregnation. The purpose of the impregnation is to depress the capillary activity of the porous façade materials and reduce the uptake of driving rain. These impregnations in liquid, gel or cream form have been used during the last decades to protect constructions against moisture, chlorides and biological growth and may help to avoid moisture problems after applying internal insulation. Modern façade impregnations are based on several types of water-based alkylsilanes or siloxanes that form an umbrella-like clear shield by reacting with the mineral substrate of the façade surface. They penetrate up to $10-50$ $\mathrm{mm}$ into the pores, while wall diffusion is still remained, so water vapour and $\mathrm{CO}_{2}$ from behind can pass unimpeded (although the drying process is significantly delayed as shown by Couto et al. [16]). In addition, they enhance the functionality of the thermal envelope, since thermal conductivity also depends on moisture content $[17,18]$, thereby yielding energy savings due to a dry wall $[19,20]$. Disadvantages relate to the need to repair cracks in the façade, the application of 
1 the impregnation and a limited durability. The product must be chosen with care and tailored to

2 the individual building requiring additional efforts in terms of simulations, laboratory tests, etc.

3 In an instructional paper by the International Association for Science and Technology of Building

4 Maintenance and the Preservation of Monuments WTA it is stated that existing buildings should

5 only be internally insulated if the façade has a driving rain protection [21]. Thus, where the

6 building is not protected by the surroundings, constructional protection like roof overhangs etc.,

7 façade hydrophobisation would be mandatory. This would especially be relevant in areas with a

8 high amount of precipitation (e.g. in Denmark). However, from a building conservational point of

9 view it can be said that although a clear impregnation does not really alter the aesthetical

10 appearance of the historic building, which often is a requirement by the authorities for listed

11 buildings, it definitely alters the materials' characteristics and properties [22].

12 Worch and Auras showed in numerical calculations and a case study of a historic 1-storey 13 transformer building that the moisture load after the application of an $80 \mathrm{~mm}$ internal mineral 14 insulation board was not critical given the relatively thin masonry wall (one brick/one and a half 15 brick) and hydrophobisation could be avoided [23]. They suggest a wait and see strategy where 16 insulation is installed and the moisture content is monitored by obtaining drill samples from 17 mortar joint crosses, which measure close to the interface between original wall and the insulation 18 (done by the end of winter over several years). Only if the moisture content is critical, a façade treatment that may include replacement of the mortar joints and impregnation should be used. So this could be a solution, but a very time-consuming one, if there is doubt about the feasibility of a 21 capillary active insulation. 
1 However, experiences with a combination of a capillary active/hydrophilic internal insulation and

driving rain protection of the external wall are still rare, although this possibly could solve a problem of especially bare masonry walls made of historic bricks that often are more inhomogeneous, softer and more porous than a standard brick and thereby more exposed to the risk of spalling under freezing conditions.

The study presented in this paper takes up this question and will by selected simulations of a typical historical wall investigate, which interior insulation systems will perform best under the given conditions. A special focus is given to the effect of impregnation including the influence of the timing for impregnation.

As a case is used an infill wall in the historical Borch's dormitory in Copenhagen. Borch's dormitory in the very centre of Copenhagen was founded in 1691 and burnt down twice, before the 3-storey solid brick building with 19 rooms was re-built as it stands today in 1825 . Since then, the external walls have not been changed much, the windows are double-glazed, floor separations are made with timber joist floors with wooden beam ends embedded in the façade wall and there is natural ventilation in the building.

\section{Material and methods}

A number of models - i.e. internal insulation systems and scenarios based on three capillary active/hydrophilic insulating materials - were tested for their hygrothermal performance with one-dimensional numerical simulations in WUFI (Wärme und Feuchte Instationär/Transient Heat and Moisture) [24], and the mould risk was calculated with the postprocessor WUFI-Bio 3.1 RC using Mould Index calculation according to VTT model. The insulation materials - autoclaved aerated concrete (AAC), calcium silicate board (CaSi) and a capillary active thermal insulation 
1 system based on rigid PUR-foam panels made capillary active by adding mortar channels of $\varnothing 4$ $\mathrm{mm}$ every $4 \mathrm{~cm}$ (IQ-Therm) - were tested with different insulation thicknesses $(30-100 \mathrm{~mm})$ and with or without driving-rain protection (impregnation equivalent to $S_{d}=0.1 \mathrm{~m}$ ) or cracks in the impregnation for the resulting heat and moisture transfer in an external masonry wall of a historic building.

Table 1. Overview of the simulated models. AAC: autoclaved aerated concrete, CS: calcium silicate board and IQ-Therm: PURfoam panels with capillary active mortar channels.

\begin{tabular}{|l|c|c|c|c|}
\hline Wall assembly & $\begin{array}{c}\text { Insulation thickness } \\
{[\mathrm{mm}]}\end{array}$ & $\begin{array}{c}\text { Without } \\
\text { impregnation }\end{array}$ & $\begin{array}{c}\text { With } \\
\text { impregnation }\end{array}$ & $\begin{array}{c}\text { With crack in } \\
\text { impregnation }\end{array}$ \\
\hline Original wall (OW) & - & $\mathrm{X}$ & $\mathrm{X}$ & - \\
\hline OW + AAC & 60 & $\mathrm{X}$ & $\mathrm{X}$ & - \\
\hline OW + AAC & 80 & $\mathrm{X}$ & $\mathrm{X}$ & - \\
\hline OW + AAC & 100 & $\mathrm{X}$ & $\mathrm{X}$ & $\mathrm{X}$ \\
\hline OW + CaSi & 30 & $\mathrm{X}$ & $\mathrm{X}$ & $\mathrm{X}$ \\
\hline OW + CaSi & 50 & $\mathrm{X}$ & $\mathrm{X}$ & - \\
\hline OW + IQ-Therm & 50 & $\mathrm{X}$ & $\mathrm{X}$ & $\mathrm{X}$ \\
\hline
\end{tabular}

8

9

The simulated wall is a $228 \mathrm{~mm}$ thick, uninsulated brick wall, plastered on the interior side and unplastered on the exterior side. It represents a typical construction of an infill wall under a window in Danish historic buildings (prior 1945). Figure 1 shows a principle drawing of the wall and the 3 positions that are used for analysis of results ( $S_{\mathrm{i}}$ : Interior surface (room side), $\mathrm{S}_{\mathrm{e}}$ : External surface (outside) and $S_{\mathrm{I}}$ : Interface between original wall and insulation). Figure 2 shows the calculation model of wall assembly with $30 \mathrm{~mm}$ CaSi insulation. The green arrow marks Interface, assumed as the most critical point in relation to moisture problems. Data in the WUFI database for the historic brick and mortar were used, see Table 2. 


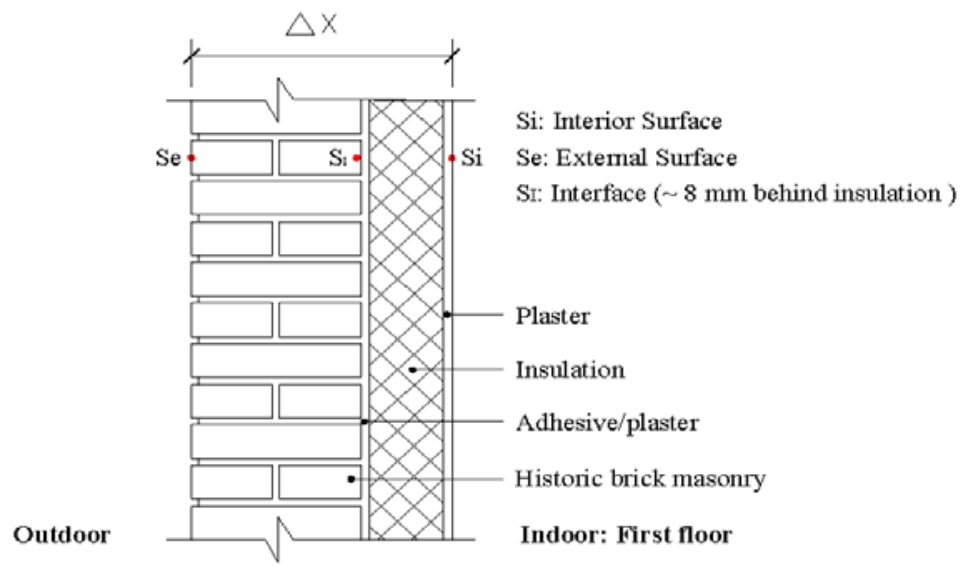

Figure 1. Principle drawing of investigated masonry wall with insulation and location, where the simulated output is used for analysis ( $\mathrm{S}_{\mathrm{i}}$ : Interior surface, $\mathrm{S}_{\mathrm{e}}$ : External surface (outside) and $\mathrm{S}_{\mathrm{l}}$ : Interface between original wall and insulation)

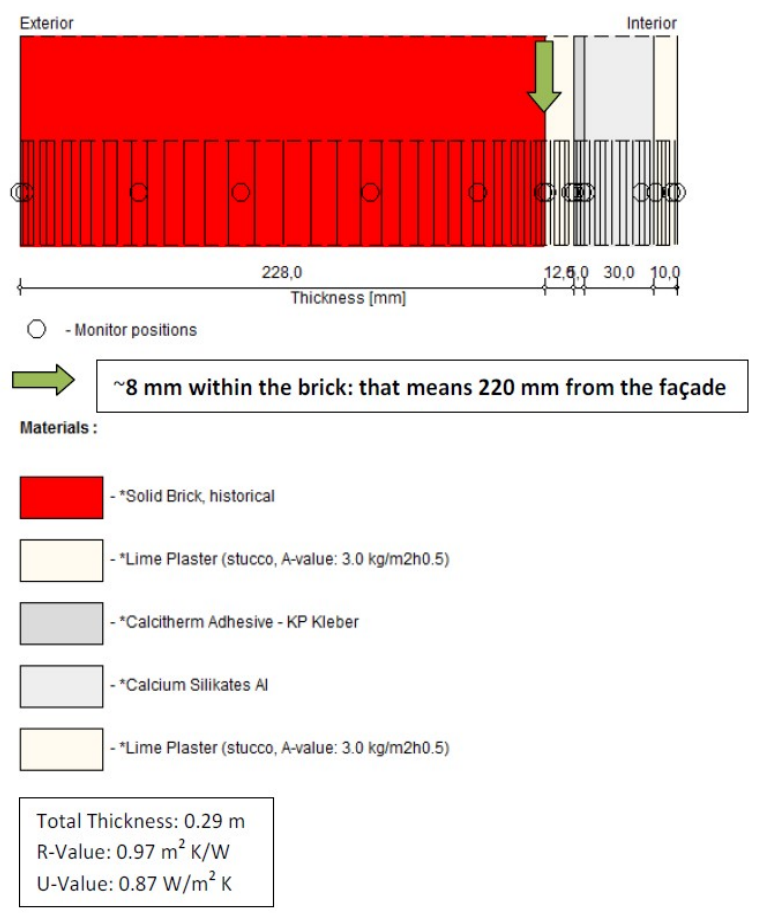

Figure 2. Simulation model (WUFI-Pro 5) of a wall assembly with $30 \mathrm{~mm}$ CaSi insulation system and indication of the position most interesting for the analysis behind the insulation (green arrow)

The analysis is done in 2 steps. In step 1, the moisture behaviour and risk of mould growth on the interior surface $\left(S_{i}\right)$ and behind the insulation (interface $S_{1}$ ) are investigated. Models showing

9 acceptable values in step 1 are further analysed regarding the heat loss, minimum temperatures on the interior and external surface (step 2).

11 The analysis in step 1 is based on the following questions: 
- Is the relative humidity between the original wall and the insulation $>80 \%$ (within a 10 -year period)?

- Is the relative humidity on the interior surface $>80 \%$ within a 10 -year period?

- Is there risk of mould growth (Mould Index $>1^{1}$ ) [25] between the wall and the insulation

$5 \quad$ (within a 10-year period)?

- Is there risk of mould growth (Mould Index $>1$ ) on the interior surface (within the last year of a 10 -year period)?

- Which influence has a façade crack with a depth of $1 \mathrm{~cm}$ on the hygrothermal behaviour of

$9 \quad$ the wall?

The analysis in step 2 is based on the following questions to support the final conclusions and recommendations:

- What is the heat loss through the interior surface of the insulated wall compared to the uninsulated wall (heat loss reduction)?

- What are the minimum temperatures at the exterior and interior surfaces during the last year of a 10-year period?

Finally, the moisture distribution across all layers of the studied wall assemblies is analysed for a 10-year period to further assess the hygrothermal performance of the wall assemblies.

\footnotetext{
${ }^{1}$ Mould Index range between 0 and 6 . The mould index $=3$ denotes a risk when the mould growth becomes visual to naked eye. In the current work $M<1$ is used as a design criterion, as $M=1$ is defined as starting the germination process.
} 


\section{$1 \quad 2.1$ Simulation model and input data}

2 The hygrothermal simulations of the wall assemblies are performed with WUFI-Pro 5.3, a

3 numerical simulation tool for coupled heat and moisture transport developed by Fraunhofer

4 Institute in Germany. Numerical discretisation of the model is illustrated in Figure 2.

5 Boundary conditions have been chosen as follows: The investigated façade is assumed to face

6 South-West direction to be on the safe side, since the South-West direction is the direction that is

7 most exposed to driving rain in Copenhagen area according to the driving rain rose (see Figure 3 ,

8 right). The building is modelled as a tall building $(>20 \mathrm{~m})$ in order to be on the safe side regarding

9 the driving rain impact, since higher buildings are more exposed to driving rain than lower

10 buildings. The wall is assumed to be vertical. The colour of the façade surface is assumed to have a

11 typical Danish bright façade brick colour. Driving rain water absorption (adhering factor of rain) is

12 set to $70 \%$ in the reference model, and reduced to approximate $1 \%$ in the models with

13 impregnation. These values are arbitrary choices and default values supported by the WUFI user

14 community [24]. Impregnation is modelled by adding a $1 \mathrm{~mm}$ layer weather resistive barrier (see

15 Table 2).

16 Weather data from Lund/Sweden were used because Copenhagen data are not available in WUFI.

17 Copenhagen is situated approximately 40 kilometres West of Lund and there are only minor

18 weather deviations between Copenhagen and Lund, since they belong to the same climate type

19 according to the Köppen-Geiger climate classification Dfb. They both have warm summer

20 continental climate with significant precipitation in all seasons. The weather data included hourly

21 values of temperature $[\stackrel{\circ}{\circ}]$, relative humidity [\%], solar radiation $\left[\mathrm{W} / \mathrm{m}^{2}\right]$, barometric pressure 
$1[\mathrm{~Pa}]$, long-wave counter radiation $\left[\mathrm{W} / \mathrm{m}^{2}\right]$ and rain load [Litres $/ \mathrm{m}^{2} / \mathrm{h}$ ] for the different orientations

2 in Lund according to WUFI. Some of the meteorological data for Lund are given in Figure 3.

3 The influence of crack in the impregnation layer and in the outermost layer of brick was modelled

4 by allowing $1 \%$ of the driving rain to penetrate $10 \mathrm{~mm}$ into construction, i.e. $9 \mathrm{~mm}$ behind the 1

$5 \mathrm{~mm}$ weather resistive barrier. This is a very simplified method to model 2D effects in a 1D model,

6 but it is used in the present analysis as this method is recommended by the WUFI user community.

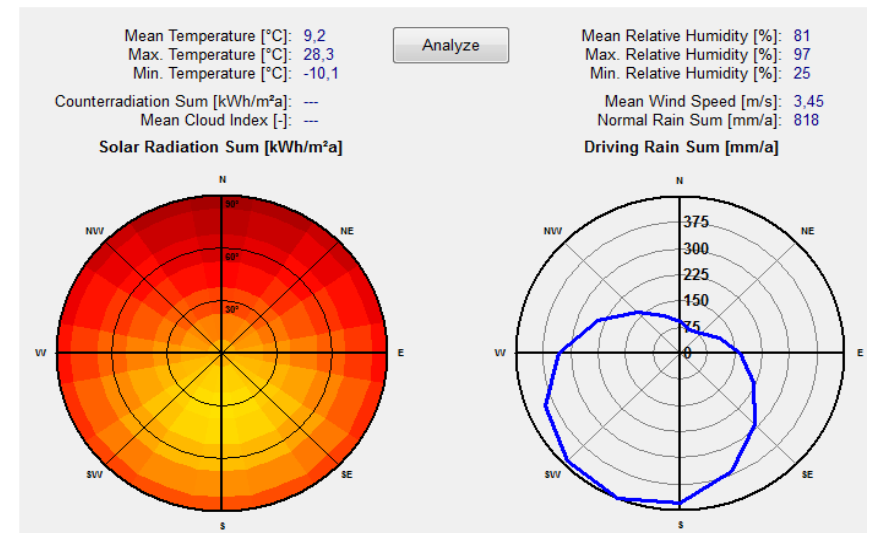

\section{Figure 3. Solar radiation (Low levels of radiation are represented by brown-red colour and high radiation levels with yellow) and driving rain sum for Lund (from WUFI database)}

The indoor moisture load was set to normal (according to EN15026). WUFI-Pro 5.3 database material properties were used in the simulated models and these are given in Table 2. The initial moisture and temperature in component are chosen as constant across component $\left(20^{\circ} \mathrm{C} ; 80 \%\right.$ RH). The simulation started on 1.12 .2013 and run 10 years. 
Table 2. Material properties for WUFI-Pro 5.3 simulation

\begin{tabular}{|c|c|c|c|c|c|c|c|c|}
\hline \multirow{3}{*}{ Materials } & Thickness & $\begin{array}{c}\text { Bulk } \\
\text { density }\end{array}$ & Porosity & $\begin{array}{l}\text { Specific } \\
\text { heat } \\
\text { capacity }\end{array}$ & $\begin{array}{c}\text { Thermal } \\
\text { conductivity }\end{array}$ & $\begin{array}{c}\text { Vapour } \\
\text { diffusion } \\
\text { resistance }\end{array}$ & \begin{tabular}{|c|} 
Moisture \\
dependent \\
thermal \\
conductivity
\end{tabular} & $\begin{array}{c}\text { Initial } \\
\text { moisture } \\
\text { content }\end{array}$ \\
\hline & $\mathrm{D}$ & $\rho$ & $\mathrm{P}$ & $C_{p}$ & $\lambda$ & $\mu$ & $\mathrm{b}$ & $\mathrm{MC}$ \\
\hline & {$[\mathrm{mm}]$} & {$\left[\mathrm{kg} / \mathrm{m}^{3}\right]$} & {$\left[\mathrm{m}^{3} / \mathrm{m}^{3}\right]$} & {$[\mathrm{J} /(\mathrm{kg} \cdot \mathrm{K})]$} & {$[\mathrm{W} /(\mathrm{m} \cdot \mathrm{K})]$} & {$[-]$} & [\%/M-\%] & {$\left[\mathrm{kg} / \mathrm{m}^{3}\right]$} \\
\hline $\begin{array}{l}\text { Weather resistive barrier } \\
\left(S_{d}=0,1 \mathrm{~m}\right)\end{array}$ & 1 & 130 & 0.001 & 2300 & 2.3 & 100 & - & 0.0 \\
\hline Solid Brick, historical & 228 & 1800 & 0.31 & 850 & 0.6 & 15.0 & 15 & 4.5 \\
\hline Interior Plaster (Gypsum Plaster) & 12 & 850 & 0.65 & 850 & 0.2 & 8.3 & 8 & 6.3 \\
\hline $\begin{array}{l}\text { Lime Plaster: } \\
\text { (stucco, A-value: } 3.0 \mathrm{~kg} / \mathrm{m}^{2} \mathrm{~h}^{0.5} \text { ) }\end{array}$ & $10 / 12$ & 1600 & 0.3 & 850 & 0.7 & 7.0 & 8 & 30.0 \\
\hline Ytong Multipor Adhesive & $5 / 10$ & 833 & 0.686 & 850 & 0.155 & 15.1 & 2.99 & 12.55 \\
\hline Ytong Multipor & $60 / 80 / 100$ & 115 & 0.96 & 850 & 0.04 & 4.1 & 1.2 & 8.1 \\
\hline Calsitherm Adhesive - KP Kleber & 5 & 270 & 0.9 & 1162 & 0.062 & 3.8 & 1.656 & 19.79 \\
\hline Calcium Silikates Al & $30 / 50$ & 222 & 0.92 & 1303 & 0.057 & 5.4 & 1.656 & 7.08 \\
\hline IQ-Fix & 5 & 1313 & 0.5 & 863 & 0.5 & 18.7 & 4.0 & 0.94 \\
\hline IQ-Therm board & 50 & 44.5 & 0.98 & 1400 & 0.033 & 69.0 & - & 1.84 \\
\hline IQ-Top & 10 & 465 & 0.81 & 1173 & 0.106 & 8.4 & 4.0 & 1.52 \\
\hline
\end{tabular}

\section{Results}

\section{$5 \quad 3.1$ Moisture behaviour and mould risk behind insulation and on the interior surface}

6 The results of the numerical hygrothermal simulations regarding the moisture behaviour of several

7 wall assemblies in terms of relative humidity and mould risk for the last year of a 10-year period

8 are given in Table 3. Compared to the original wall, all types of wall assemblies show the same

9 outcome after the application of insulation, since the relative humidity behind the insulation is high ( $\mathrm{RH}>80 \%$ ) and there is a high risk of mould growth (Mould Index 6, where the max.

11 tolerable value is 1). However, application of insulation results for the most wall assemblies in a dryer interior surface vs. wetter surface in the original wall, while only the two systems with

13 calcium silicate insulation show unacceptable high relative humidity and thus mould risk. In all cases, adding façade impregnation results in a dryer surface behind the insulation (Interface $\mathrm{S}_{\mathrm{I}}$ ) 
1 and the surfaces of the interior side $\left(S_{i}\right)$ of the insulation are without risk of mould growth. While

2 this in the most cases is a feasible solution, it is not the case of AAC insulation $(60,80,100 \mathrm{~mm})$,

3 where the relative humidity behind the insulation (Interface $S_{I}$ ) is high, lowest for the thinnest 60

$4 \mathrm{~mm} \mathrm{AAC}$ insulation and highest for the thickest $(100 \mathrm{~mm})$. The simulation of the effect of a crack

5 in the impregnation layer and the exterior side of brick in three models (one from each insulation

6 material: AAC, CaSi, IQ-Therm) shows a somewhat higher relative humidity and mould risk behind

7 the insulation (Interface $S_{1}$ ) compared to the wall assemblies without a crack, but no effect is seen

8 on the interior surface $\left(S_{i}\right)$. 
Table 3. Moisture behaviour behind insulation (Interface $\left.S_{1}\right)$ and on the interior surface $\left(S_{i}\right)$ of several walls with capillary active insulation. Last year of a 10-year period is used for analysis. Mould Index is given as the maximum value reached during this year.

\begin{tabular}{|c|c|c|c|c|c|c|c|c|c|c|c|c|c|c|c|}
\hline \multicolumn{4}{|c|}{ Wall assembly and specifications } & \multicolumn{12}{|c|}{ Moisture behaviour of wall } \\
\hline & \multirow{3}{*}{ 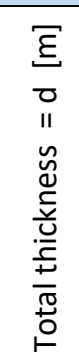 } & \multirow{3}{*}{ 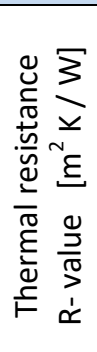 } & \multirow{3}{*}{ 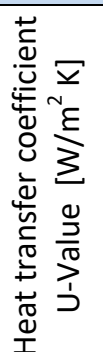 } & \multicolumn{4}{|c|}{ Original wall $(O W)+$ Insulation } & \multicolumn{4}{|c|}{ OW + insulation + impregnation } & \multicolumn{4}{|c|}{$\begin{array}{c}\text { OW }+ \text { insulation }+ \text { impregnation } \\
+1 \mathrm{~cm} \text { deep crack }\end{array}$} \\
\hline & & & & \multicolumn{2}{|c|}{$\begin{array}{c}\text { Interface } \\
\mathrm{S}_{\mathrm{I}}\end{array}$} & \multicolumn{2}{|c|}{$\begin{array}{c}\text { Interior surface } \\
\qquad S_{i}\end{array}$} & \multicolumn{2}{|c|}{$\begin{array}{c}\text { Behind insulation } \\
\text { Interface } S_{\mid}\end{array}$} & \multicolumn{2}{|c|}{$\begin{array}{c}\text { Interior surface } \\
\qquad \mathrm{S}_{\mathrm{i}}\end{array}$} & \multicolumn{2}{|c|}{$\begin{array}{c}\text { Behind insulation } \\
\text { Interface } S_{\mid}\end{array}$} & \multicolumn{2}{|c|}{$\begin{array}{c}\text { Interior surface } \\
\mathrm{S}_{\mathrm{i}}\end{array}$} \\
\hline & & & & $\mathrm{RH}>80 \%$ & $\begin{array}{l}\text { Mould } \\
\text { Index }\end{array}$ & $\begin{array}{l}\mathrm{RH}[\%] \\
\text { (range) }\end{array}$ & $\begin{array}{l}\text { Mould } \\
\text { Index }\end{array}$ & $\mathrm{RH}>80 \%$ & $\begin{array}{l}\text { Mould } \\
\text { Index }\end{array}$ & $\begin{array}{l}\mathrm{RH}[\%] \\
\text { (range) }\end{array}$ & $\begin{array}{l}\text { Mould } \\
\text { Index }\end{array}$ & $\mathrm{RH}>80 \%$ & $\begin{array}{l}\text { Mould } \\
\text { Index }\end{array}$ & $\begin{array}{l}\mathrm{RH}[\%] \\
\text { (range) }\end{array}$ & $\begin{array}{l}\text { Mould } \\
\text { Index }\end{array}$ \\
\hline \multicolumn{16}{|c|}{ Uninsulated wall } \\
\hline $\begin{array}{l}\text { Original wall (OW) } \\
228 \mathrm{~mm} \text { uninsulated }\end{array}$ & 0.24 & 0.38 & 1.77 & Yes* & $0 *$ & $52-100$ & 4.2 & No* & $0 *$ & $48-66$ & 0 & - & - & - & - \\
\hline \multicolumn{16}{|c|}{ Insulated wall } \\
\hline$O W+A A C 60 \mathrm{~mm}$ & 0.32 & 1.8 & 0.51 & Yes & 6 & $41-64$ & 0 & Yes & 1.6 & $38-61$ & 0 & - & - & - & - \\
\hline $\mathrm{OW}+\mathrm{AAC} 80 \mathrm{~mm}$ & 0.34 & 2.24 & 0.41 & Yes & 6 & $40-63$ & 0 & Yes & 2.5 & $37-61$ & 0 & - & - & - & - \\
\hline$O W+A A C 100 \mathrm{~mm}$ & 0.36 & 2.69 & 0.35 & Yes & 6 & $39-63$ & 0 & Yes & 2.8 & $37-61$ & 0 & Yes & 3.3 & $37-61$ & 0 \\
\hline $\mathrm{OW}+\mathrm{CaSi} 30 \mathrm{~mm}$ & 0.29 & 0.97 & 0.87 & Yes & 6 & $46-100$ & 3.8 & No & 0 & $41-63$ & 0 & Yes & 0 & $41-63$ & 0 \\
\hline $\mathrm{OW}+\mathrm{CaSi} 50 \mathrm{~mm}$ & 0.31 & 1.3 & 0.67 & Yes & 6 & $46-100$ & 3.2 & No & 0 & $40-62$ & 0 & - & - & - & - \\
\hline $\mathrm{OW}+\mathrm{IQ}$-Therm $50 \mathrm{~mm}$ & 0.31 & 2.0 & 0.46 & Yes & 6 & $38-62$ & 0 & No & 0.04 & $38-62$ & 0 & Yes & 0.5 & $38-62$ & 0 \\
\hline
\end{tabular}




\section{$1 \quad 3.2$ Heat loss through the wall and surface temperatures}

2 Table 4 shows heat loss through the wall and the minimum temperatures of the exterior and

3 interior surface of the moisture safe wall assemblies found above compared to the original wall.

4 The heat losses through the interior surface after insulation ranged from $9.7\left[\mathrm{~W} / \mathrm{m}^{2}\right]$ for the model

5 with a $30 \mathrm{~mm}$ calcium silicate insulation with façade impregnation (heat loss reduction $73 \%$ ) to

$65.1\left[\mathrm{~W} / \mathrm{m}^{2}\right]$ for the model with the $50 \mathrm{~mm}$ lQ-Therm insulation (heat loss reduction $~ 86 \%$ )

7 compared to $35.3\left[\mathrm{~W} / \mathrm{m}^{2}\right]$ in the original, uninsulated wall.

Table 4. Heat loss through the outer wall and minimum temperatures on the interior and external surface

\begin{tabular}{|l|c|c|c|c|}
\hline Wall assembly & $\begin{array}{c}\text { Heat Loss_si } \\
{\left[\mathbf{W} / \mathrm{m}^{2}\right]}\end{array}$ & $\begin{array}{c}\text { Heat Loss } \\
\text { reduction } \\
{[\%]}\end{array}$ & $\begin{array}{c}\mathbf{T}_{\text {Se_min }} \\
{\left[{ }^{\circ} \mathbf{C}\right]}\end{array}$ & $\begin{array}{c}\mathbf{T}_{\text {Si_min }} \\
{\left[{ }^{\circ} \mathbf{C}\right]}\end{array}$ \\
\hline Original wall (OW) & 35.3 & reference & -4.2 & 9.2 \\
\hline Original wall (OW) + impregnation & 19.4 & 45 & -5.3 & 14.5 \\
\hline OW + CaSi (30 mm) + impregnation & 9.7 & 73 & -6.4 & 17.4 \\
\hline OW + CaSi (30 mm) + impregnation + crack & 9.7 & 72 & -6.1 & 17.4 \\
\hline OW + CaSi (50 mm) + impregnation & 7.5 & 79 & -6.6 & 18.0 \\
\hline OW + IQ-Therm (50 mm) + impregnation & 5.1 & 85 & -6.9 & 18.7 \\
\hline OW + IQ-Therm (50 mm) + impregnation + crack & 5.2 & 85 & -6.6 & 18.6 \\
\hline
\end{tabular}

At the same time, adding insulation made the external surface colder as the minimum temperature of the external surface during the last year of a 10-year period decreased from around $-4.2{ }^{\circ} \mathrm{C}$ (uninsulated original wall) to around $-6.9^{\circ} \mathrm{C}$ in the model with the $50 \mathrm{~mm}$ IQ-Therm insulation and impregnation. In contrast to that, there can be seen major gains in minimum temperature at the interior surface as it increases from around $9.2{ }^{\circ} \mathrm{C}$ (uninsulated wall) to around $18.7^{\circ} \mathrm{C}$. The application of a façade impregnation alone to the uninsulated wall resulted also in a substantial gain in minimum temperature at the interior surface as it increases from $9.2{ }^{\circ} \mathrm{C}$

17 (uninsulated wall) to $14.5^{\circ} \mathrm{C}$. The calculation of heat losses in 2 models including a façade crack shows the heat losses are only slightly higher than in the models without a crack (max. $0.25 \%$ ) which results in negligible temperature deviations of the exterior and interior surface. Adding 
1 façade impregnation to the uninsulated reference wall resulted in $45 \%$ heat loss reduction and a

2 temperature drop of around $1{ }^{\circ} \mathrm{C}$, since it decreases from $-4.2{ }^{\circ} \mathrm{C}$ to $-5.3{ }^{\circ} \mathrm{C}$.

\section{$4 \quad 3.3$ Necessary insulation thickness according to Danish Building regulations}

5 According to the current Danish Building regulations, the required U-value (the heat transfer

6 coefficient) for exterior walls is $0.20 \mathrm{~W} /\left(\mathrm{m}^{2} \mathrm{~K}\right)$. To fulfil this, the insulation thickness should be

7 higher than in the analysed models. An additional analysis of the necessary insulation thickness

8 and the influence of the insulation thickness on some hygrothermal parameters was performed in

9 WUFI and the results are given in Table 5 for IQ-Therm insulation. In this case, the necessary

10 insulation thickness is $150 \mathrm{~mm}\left(0.19 \mathrm{~W} / \mathrm{m}^{2} \mathrm{~K}\right)$.

Table 5. Results of hygrothermal analysis of necessary thickness of IQ-Therm to fulfil the Danish Building Regulations BR 10. Values are obtained from WUFI simulations.

\begin{tabular}{|c|c|c|c|c|}
\hline \multirow{2}{*}{ IQ-Therm } & \multicolumn{4}{|c|}{ Insulation thickness } \\
\hline & $50 \mathrm{~mm}$ & $80 \mathrm{~mm}$ & $100 \mathrm{~mm}$ & $150 \mathrm{~mm}$ \\
\hline Total thickness of wall: [m] & 0.31 & 0.34 & 0.36 & 0.41 \\
\hline R-Value: $\left[\mathrm{m}^{2} \mathrm{~K} / \mathrm{W}\right]$ & 2.0 & 2.9 & 3.5 & 5.0 \\
\hline U-Value: $\left[\mathrm{W} / \mathrm{m}^{2} \mathrm{~K}\right]$ & 0.46 & 0.32 & 0.27 & 0.19 \\
\hline $\mathrm{T}_{\text {Si min }}:[\mathrm{C}]$ & 18.7 & 19.1 & 19.2 & 19.1 \\
\hline $\mathrm{RH}_{\text {Si max }}:[\%]$ & 61.4 & 61.0 & 60.8 & 60.6 \\
\hline Heat Loss: $Q_{\text {Si average }}\left[\mathrm{W} / \mathrm{m}^{2}\right]$ & 5.1 & 3.6 & 3.0 & 2.2 \\
\hline
\end{tabular}

\subsection{Cross sectional view of some wall assemblies}

For better understanding of the hygrothermal performance of the wall assemblies, temperature, relative humidity and moisture content distribution across all layers were studied for the last year of the simulated 10-year period. The red (temperature), green (relative humidity) and blue (moisture content) zones show the range of values, while the red, green and blue lines show the 
Figure 4 shows the cross sectional view of the original, uninsulated reference wall, where it is seen that this is a wet wall with unacceptable high moisture (water) content and a high relative

5 humidity level across the wall. The minimum interior surface temperature is low $\left(T_{\text {si_min }} 9.2^{\circ} \mathrm{C}\right)$.

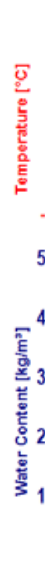

Se: External Surface
Min.

surface

temp.

$9.2{ }^{\circ} \mathrm{C}$

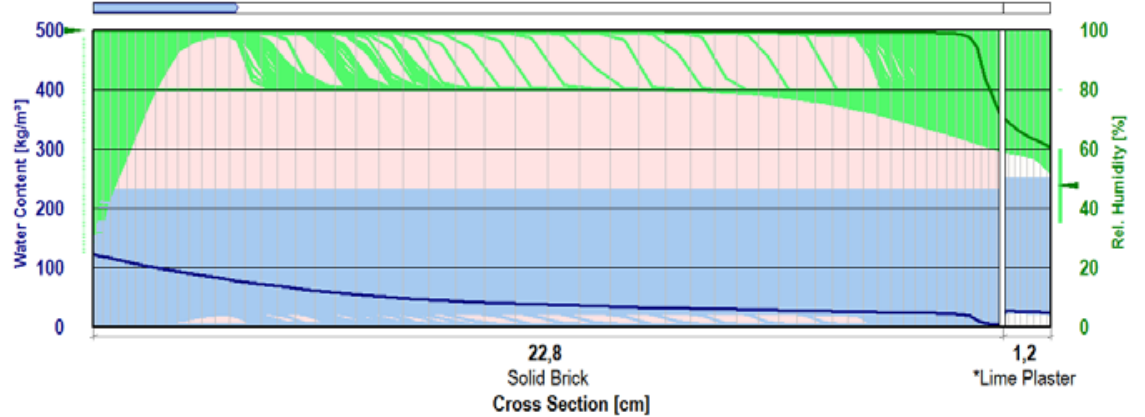

Si: Interior Surface

Figure 4. Original wall, uninsulated. Temperature, relative humidity and moisture content distribution across all layers for the last year of the simulated 10-year period. The red (temperature), green (relative humidity) and blue (moisture content) zones show the range of values. Red, green and blue lines show the meanvalues.

Figure 5 shows the same wall with a driving rain protection (façade impregnation). The moisture content drops dramatically (blue zone) and the interior surface becomes somewhat warmer ( $T_{\text {si_min }}$ $\left.14.5^{\circ} \mathrm{C}\right)$. 


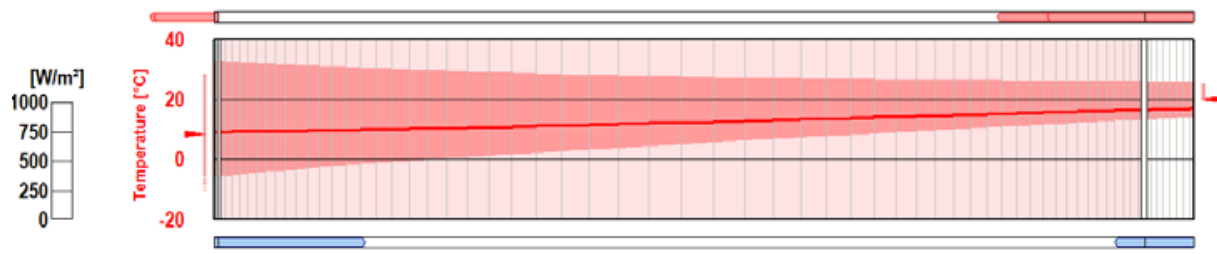

Min.

surface

temp.

$14.5^{\circ} \mathrm{C}$

[mm/h]
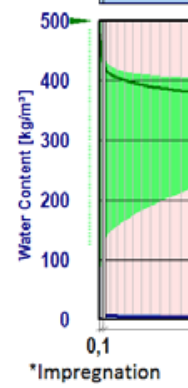

\section{Se: External Surface}

Si: Interior Surface

3

Figure 5. Impregnated original wall, uninsulated. Temperature, relative humidity and moisture content distribution across all layers for the last year of the simulated 10-year period. The red (temperature), green (relative humidity) and blue (moisture content) zones show the range of values. Red, green and blue lines show the mean values.

Figure 6 shows the same wall but now with $50 \mathrm{~mm}$ lQ-Therm thermal insulation. There is no

longer any moisture risk and the temperature of the interior surface has increased to an

acceptable level $\left(18.7^{\circ} \mathrm{C}\right.$ minimum).
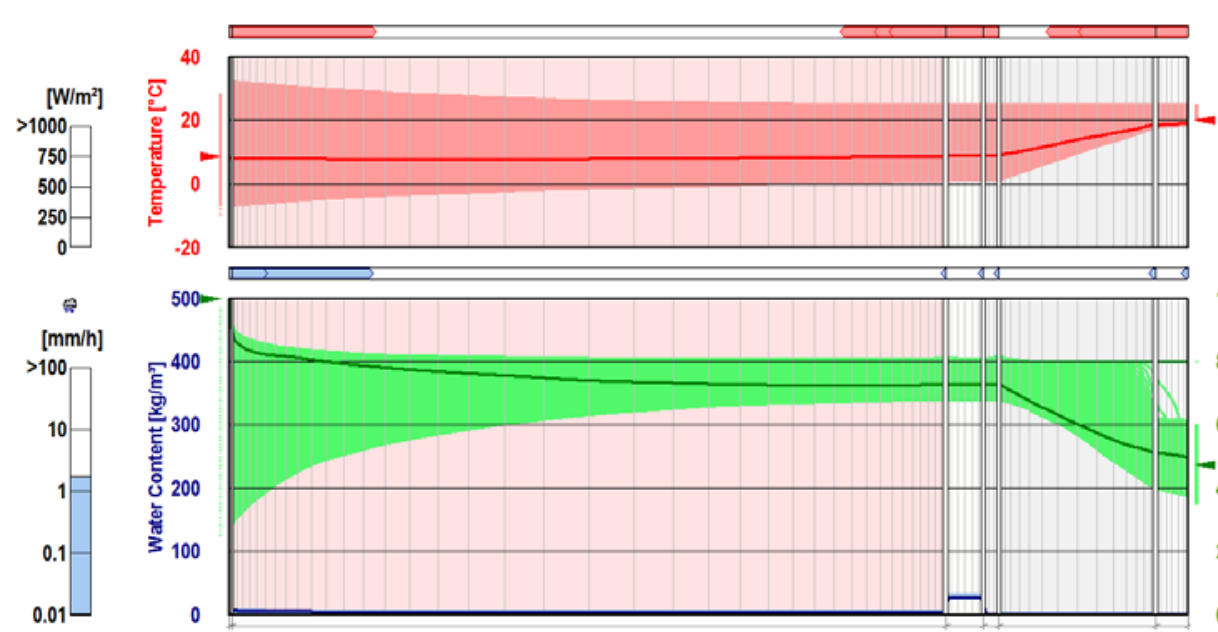

Min.

surface

temp.

$18.7^{\circ} \mathrm{C}$

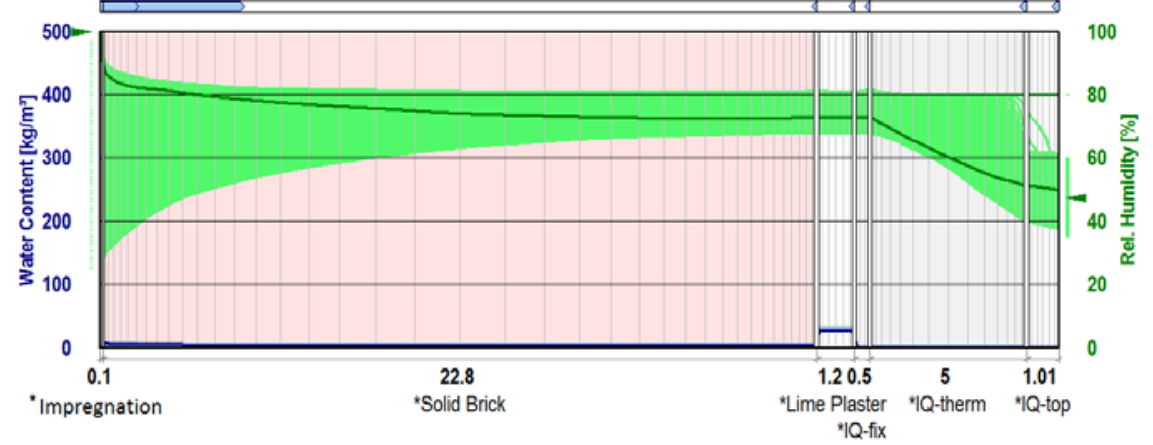

Cross Section $[\mathrm{cm}]$

Si: Interior Surface

Figure 6. Impregnated original wall + IQ-Therm $50 \mathrm{~mm}$. Temperature, relative humidity and moisture content distribution across all layers for the last year of the simulated 10 -year period. The red (temperature), green (relative humidity) and blue (moisture content) zones show the range of values. Red, green and blue lines show the mean values. 

surface temperatures are $17.9{ }^{\circ} \mathrm{C}$ on the unimpregnated and $18.6{ }^{\circ} \mathrm{C}$ on the impregnated wall.
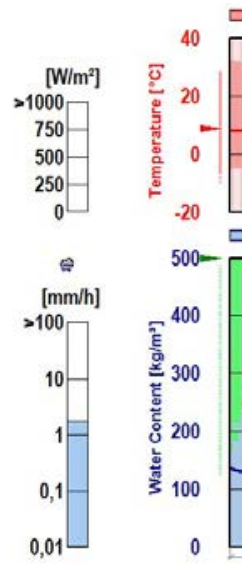

\section{Se: External Surface}

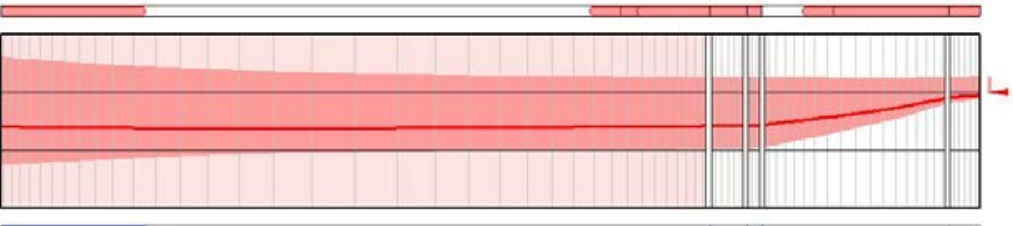

Min.

surface temp.

$17.9^{\circ} \mathrm{C}$

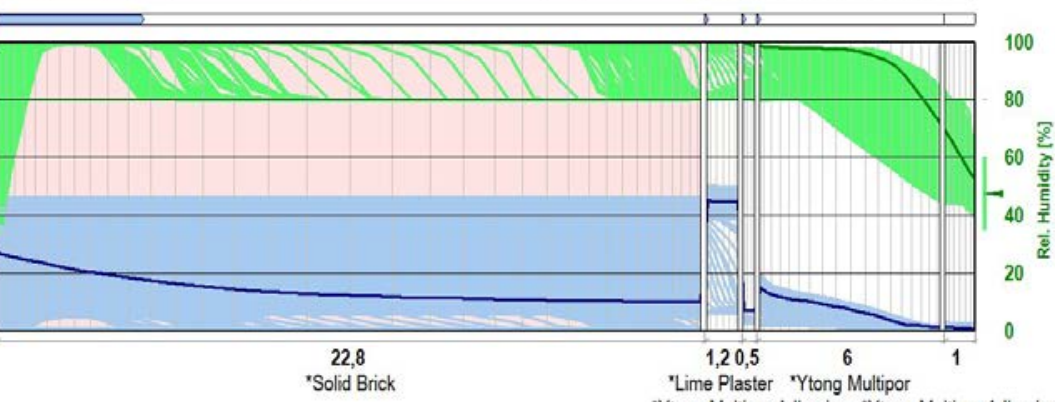

Cross Section $[\mathrm{cm}]$

"Ytong Multipor Adhesive "Ytong Multipor Adhesive

Si: Interior Surface

Figure 7. Original wall + AAC internal insulation $60 \mathrm{~mm}$. Temperature, relative humidity and moisture content distribution across all layers for the last year of the simulated 10 -year period. The red (temperature), green (relative humidity) and blue (moisture content) zones show the range of values. Red, green and blue lines show the mean values.
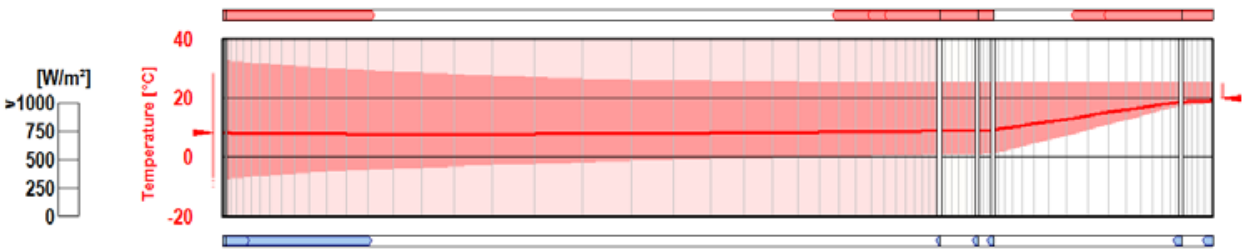

Min.

surface

temp.

$18.6{ }^{\circ} \mathrm{C}$
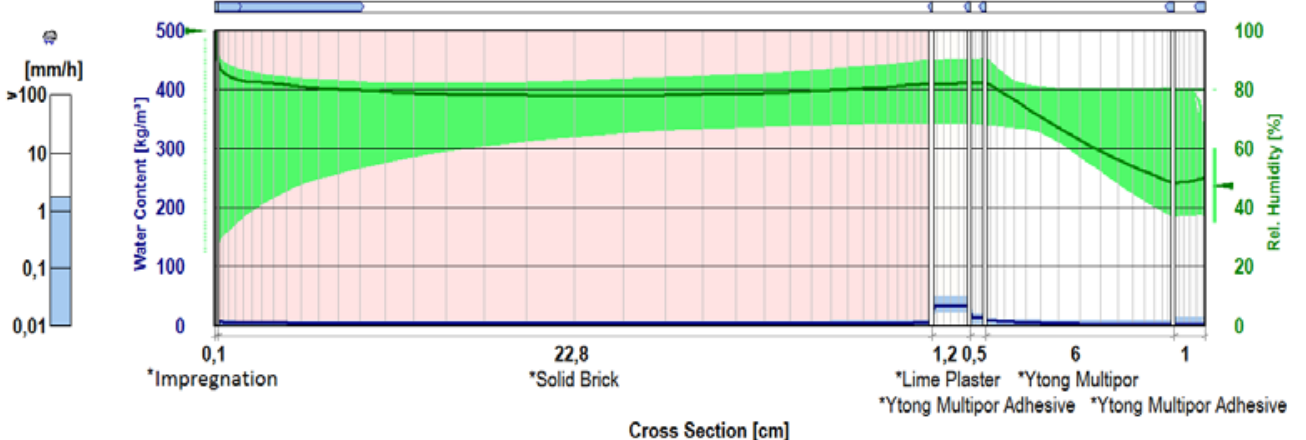

Se: External Surface

Si: Interior Surface

Figure 8. Impregnated original wall + AAC $60 \mathrm{~mm}$. Temperature, relative humidity and moisture content distribution across all layers for the last year of the simulated 10-year period. The red (temperature), green (relative humidity) and blue (moisture content) zones show the range of values. Red, green and blue lines show the mean values. 
1 Figure 9 shows the effect of a $1 \mathrm{~cm}$ deep façade crack for the impregnated original wall insulated with $50 \mathrm{~mm}$ IQ-Therm insulation. It can be seen, that the area behind the façade is obviously much wetter (higher water content and $\mathrm{RH}$ ) due to the ingress of water. But this does neither affect the room side very much nor the area behind the insulation. Thus, despite the crack, this wall assembly is still a moisture-safe solution in regard to moisture level behind the insulation and on the interior surface, and with a warm interior surface $\left(T_{\text {si_min }} 18.6^{\circ} \mathrm{C}\right)$.

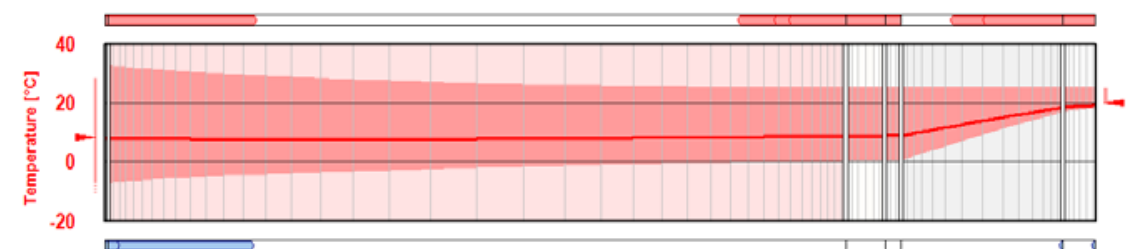

Min.

surface

temp.

$18.6{ }^{\circ} \mathrm{C}$
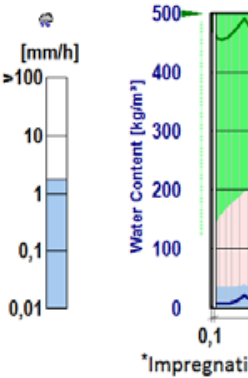

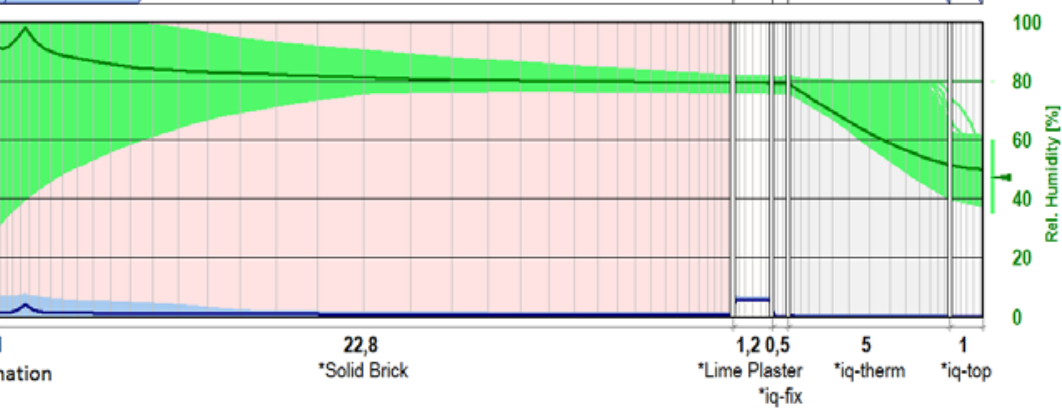

Cross Section $[\mathrm{cm}]$

Figure 9. Impregnated original wall + IQ-Therm $50 \mathrm{~mm}+$ façade crack $1 \mathrm{~cm}$ deep. Temperature, relative humidity and moisture content distribution across all layers for the last year of the simulated 10-year period. The red (temperature), green (relative humidity) and blue (moisture content) zones show the range of values. Red, green and blue lines show the mean values.

\subsection{Risk of mould growth behind the insulation}

Risk of mould growth (expressed as Mould Index) behind the original brick wall with different insulation types and impregnation was simulated for selected models. The analysis has been carried out for 10 years, but is only shown for the first 5 years, since the Mould risk does not change over the last 5 years. 
1 Mould indices for the uninsulated original wall and impregnated uninsulated original wall respectively showed that there is no risk of mould growth $\left(\mathrm{MI}_{\max }=0\right.$ ) behind the lime plaster (i.e.

$3220 \mathrm{~mm}$ behind the façade) in these walls throughout a 5-year period. This common pattern is 4 surprising, since the unimpregnated and impregnated uninsulated original wall otherwise show 5 completely different moisture behaviour, where the unimpregnated wall has high moisture content and the impregnated wall very low moisture content. However, further investigation of the moisture behaviour of the unimpregnated uninsulated original wall revealed that the measuring point behind the lime plaster is just the driest area of the whole wall (see also Figure 4). For most wall assemblies with insulation, the moisture risk pattern is quite similar to each other, since relative humidity behind the insulation is increasing in the year after the application, this dries out again and is then stable at least from year 2 .

Figure 10 shows that the mould risk hardly increases after application of $50 \mathrm{~mm}$ IQ-Therm insulation to the impregnated original wall, and no increase is expected after the dry-out effect. After application of AAC internal insulation $(60 / 80 / 100 \mathrm{~mm})$, the mould risk increases during the first 6 months and stays constant on a critical, unacceptable high level $\left(\mathrm{MI}_{\max }=6\right)$ until the end of a 5-year period. Thus, no dry-out effect is seen in AAC and there is no difference between the different thicknesses.

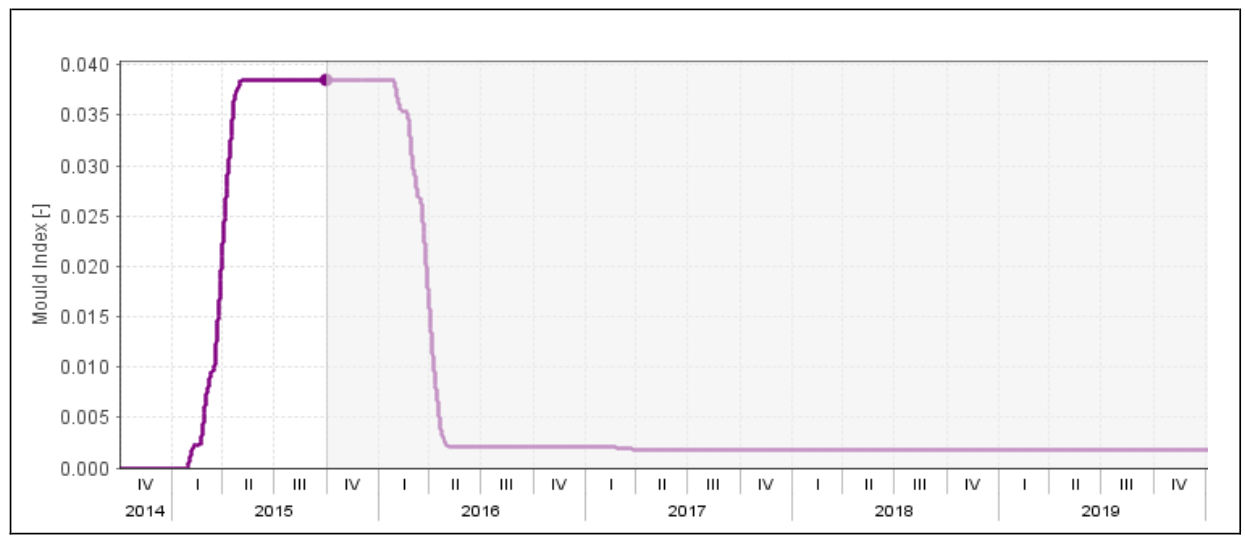

Figure 10. Mould index for impregnated original wall + IQ-Therm $50 \mathrm{~mm}$ 
1 Figure 11 shows the risk of mould growth after AAC insulation, but now with a façade 2 impregnation. This clearly demonstrates a slight decrease after the usual increase in mould risk 3 during the first year depending on insulation thickness, where the thickest $100 \mathrm{~mm}$ has the highest risk $\left(\mathrm{MI}_{\max }=2.8\right)$, the $80 \mathrm{~mm}$ insulation a lower risk $\left(\mathrm{MI}_{\max }=2.5\right)$ and the $60 \mathrm{~mm}$ the lowest risk

$5 \quad\left(\mathrm{MI}_{\max }=1.6\right)$. For all 3 cases, mould risks are on constant levels for the rest of the 5-year period.

6

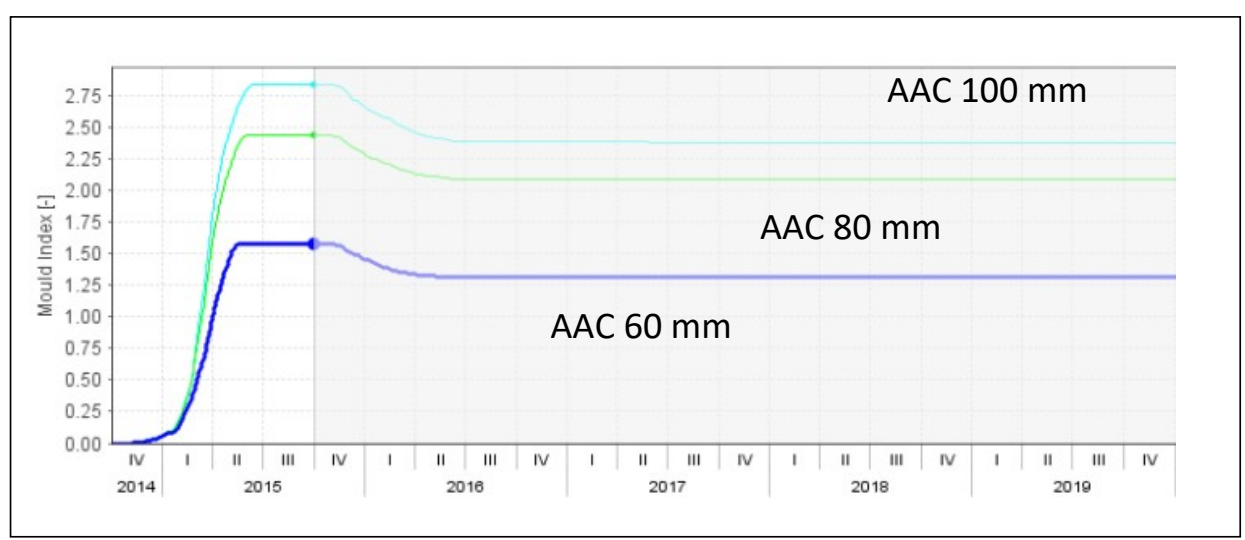

Figure 11. Mould index for impregnated original wall + AAC 60/80/100 mm

Figure 12 shows the effect of a façade crack occurring in the impregnated wall with $50 \mathrm{~mm}$ IQTherm insulation. As usual, the mould risk increases in the beginning, but there is no dry-out effect afterwards, since the risk further increases slightly due to the greater ingress of water $\left(\mathrm{MI}_{\max }=\right.$ 0.52). However, it will be stable on an acceptable level $(\mathrm{MI}<1)$ after 3-years in a 5-yearperiod.

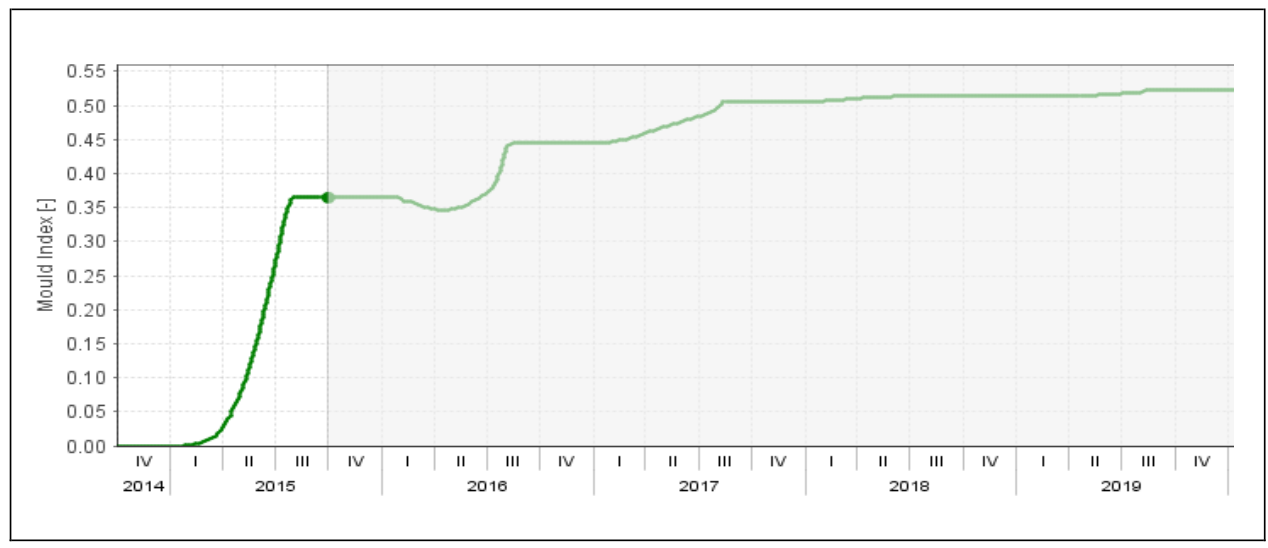

Figure 12. Mould index for impregnated original wall + IQ-Therm $50 \mathrm{~mm}+$ façade crack $1 \mathrm{~cm}$ deep 


\section{4. Discussion}

\section{$2 \quad 4.1$ Discussion of the results}

3 This hypothesis-generating initial study has been the first step within a greater research project at

4 DTU on the topic of internal thermal insulation of historic buildings (a subsequent Time-of-

5 wetness analysis can be found in [26]). To validate the results of this study, they will be followed

6 up by case studies with on-site measurements. Simulations can, however, be used to give a picture

7 of expected performance in reality. E.g. Häupl et al. found a good coherence between numerical

8 simulations and field data regarding capillary active calcium silicate insulation [10]. When

9 deviations occur, this can often be explained by extreme, unusual weather conditions [10] or other

10 assumptions.

11 It can be hypothesized that the hygrothermal conditions found in the present study represent the worst case scenario due to the over-dimensioning of some boundary conditions (building height and direction with more rain) and also relatively strict assessment of the maximum acceptable relative humidity level (max. $80 \%$ ). The $80 \%$ relative humidity "threshold" has been used for safety reasons, since wooden beam ends and laths (not included in the simulations of the present study) which are more susceptible to mould growth, normally can be found embedded in historic

17 walls.

For the Copenhagen dormitory, none of the simulated more or less capillary active insulation materials AAC, calcium silicate or IQ-Therm in different thicknesses (max. $100 \mathrm{~mm}$ ) fulfilled the requirement of a relative humidity level behind the insulation lower than $80 \%$ combined with no

21 risk of mould growth (Mould index $\leq 1$ ) during the last year obtained in a period of 10 years, since all insulation types and thicknesses resulted in RH levels over $80 \%$ and Mould Index 6 . This is in 
1 line with results from Vereecken [12,13] who also found high moisture content in capillary active

2 insulation systems. One could argue that we used a quite strict criterion (Mould Index $>1$ ) [25] for

3 the conditions between the wall and the insulation, while others have used $\mathrm{MI}>3$ for surfaces

4 that are not visible. However, at this level of the analysis, using MI > 3 as a critical value would not

5 have changed the conclusion.

6 There is no doubt that all the tested insulation systems have been shown feasible i.e. moisture

7 safe in other objects, but as the performance depends on e.g. driving rain load and thickness of

8 the wall, it must be assessed in each specific case. In the present study, these factors - in some of

9 the cases - have been unfavourable due to high amount of driving rain and a thin wall.

10 The internal insulation without driving rain protection resulted in all cases in too high relative

11 humidity and subsequently in an increased risk of mould growth behind the insulation during the

12 first year after application from Mould index 0 (no growth) to 6 meaning heavy and tight mould

13 growth that covers about $100 \%$ (Table 3, Figure 7). Condensation on the interior surface was only

14 a problem in one material, calcium silicate, where the relative humidity is up to $100 \%$, which also

15 resulted in a risk of mould growth (Mould index $>1$ [25]). Although calcium silicate has a very high

$16 \mathrm{pH}$ value that should prevent the growth of mould species, it cannot be totally avoided when e.g.

17 wallpaper is applied on the insulated wall providing the necessary nutrients for mould growth.

18 Thus, the calculated moisture and mould growth risk are too high to result in a completely

19 moisture safe solution.

20 It makes a crucial difference adding a driving rain protection, i.e. impregnation, to the façade. The

21 lowest values regarding relative humidity and mould growth risk were found for the following 22 insulation types: $30 \mathrm{~mm}$ calcium silicate insulation, $50 \mathrm{~mm}$ calcium silicate insulation and $50 \mathrm{~mm}$ 
1 IQ-Therm insulation (Table 3, Figure 6, Figure 10). However, even with a driving rain protection, all models with AAC insulation $(60-100 \mathrm{~mm})$ did not meet the criteria for a moisture safe solution

3 given the chosen boundary conditions (Figure 8, Figure 11). They fail because the relative humidity

4 behind the insulation is too high, although the risk of mould growth decreased compared to the

5 unprotected façade, but not enough to be on an acceptable level. The reason for the AAC

6 outcomes is most likely the relatively low capillary transport properties and vapour diffusion

7 resistance of AAC (Table 2).

8 Condensation and risk of mould growth on the interior surface is not seen in any models with a

9 façade protection. The model without insulation but only with impregnation shows also a moisture safe performance with a remarkable increase of the minimum interior surface

11 temperature to a more acceptable level i.e. above the dew point temperature (Figure 5). According to recommendations by the Danish Building Research Institute [27] (based on EN ISO 13788) and depending on moisture load class, the critical surface temperatures during winter time are $13.8{ }^{\circ} \mathrm{C}$ and $15.9{ }^{\circ} \mathrm{C}$ for class 2 and 3 respectively (with the assumption that the room 15 temperature is $20{ }^{\circ} \mathrm{C}$, exterior temperature is -0.6 and $\mathrm{RH}_{\max }$ for interior surface is $75 \%$ ). Thus, adding solely impregnation, the interior surface temperature increased the minimum surface temperature from $9.2{ }^{\circ} \mathrm{C}$ to $14.5^{\circ} \mathrm{C}$ due to a reduction of heat loss through the wall by $45 \%$, since the impregnation makes the wall drier and a dry wall insulates much better than a wet wall (Table 4). This effect was also shown in $[17,18]$. In the case of masonry walls this is especially significant, 20 since the unprotected/bare brick's thermal conductivity increases by $20 \%$ each time the moisture content increases $1 \%$ [28]. 
1 Although an almost $100 \%$ protection is possible when impregnations are applied in the right way by experts, the durability varies a lot. Measurements in Germany have shown a lifetime of $>30$ years in some objects, while it only lasted a few years in other objects [29]. That means that the treatment needs maintenance and may be repeated after some years. It can be seen that especially the (coating) industry focuses on the many advantages of their products while on the other side experts involved in conservation of listed buildings (architects, engineers) are sceptical.

On a façade that was treated with an impregnation, the effect of a $1 \mathrm{~cm}$ deep crack was only locally limited behind the façade. Thus, the interior surface and the area behind the insulation were hardly affected by the ingress of water through the relatively little crack (Figure 9, Figure 12). However, there is a risk of freezing behind the façade that may result in damage if much moisture penetrates the wall. It has been shown that the evaporation of the trapped moisture behind the surface of the façade is impaired because of the impregnation [22]. Even though, the main reason for the wetter wall is rather that the impregnated façade (above the crack) results in a lot of runoff into the crack, which creates a greater moisture load on the impregnated façade than in an unimpregnated façade [30].

The thermal resistance levels of thin capillary active insulations are not compatible with the best insulations on the market today using other technologies (mineral wools, VIP's, Aerogel etc.). However, it was additionally calculated (Table 5) for the best performing insulation type (IQTherm) how the hygrothermal behaviour would be in case of a much thicker and thereby more effective insulation. Although the requirement of a $U$-value of $0.20[\mathrm{~W} / \mathrm{m} 2 \mathrm{~K}]$ according to $B R 10$ [31] for external wall of rooms heated $>15^{\circ} \mathrm{C}$ is not necessarily applicable for retrofit projects of historic listed buildings under Monument Protection, a calculation showed that $150 \mathrm{~mm}$ IQ-Therm insulation would be necessary to fulfil this requirement. In the cross section view of the wall (not 
1 shown), the $150 \mathrm{~mm}$ Q-Therm insulation also shows no critical moisture accumulation even with this greater thickness. For the $150 \mathrm{~mm}$ insulation, gains in terms of a warmer interior surface

3 temperature are $+0.4^{\circ} \mathrm{C}$, while the relative humidity decreases $0.8 \%$ on the interior surface $\left(\mathrm{RH}_{\mathrm{si}}\right)$

4 and the heat loss $\left(Q_{\mathrm{si}}\right)$ is further reduced by $56.0 \%$ compared to the $50 \mathrm{~mm}$ insulation (Table 5 ).

\section{$6 \quad 4.2$ Effect of impregnation and internal insulation on the drying of the wall}

7 The results of the studied simulation cases pointed out that reduction of the driving rain load on a 8 façade has a clear positive effect on the hygrothermal performance of a massive brick wall: it 9 reduces the moisture content of the entire wall. Additional simulations were performed to study how application of impregnation affects the drying out process of the wall and if there is an

11 optimal time of the year, impregnation and internal insulation should beapplied.

Figure 13 presents average moisture content of the brick in a $228 \mathrm{~mm}$ thick, South-West facing wall for 4 different cases. Moisture content of the wall has been simulated for 5 years without impregnation. Then impregnation is added and the simulation is carried further. Figure 13 shows that in all cases the wall is able to dry out within a year. However, impregnation in March and June gives the shortest drying out period. 


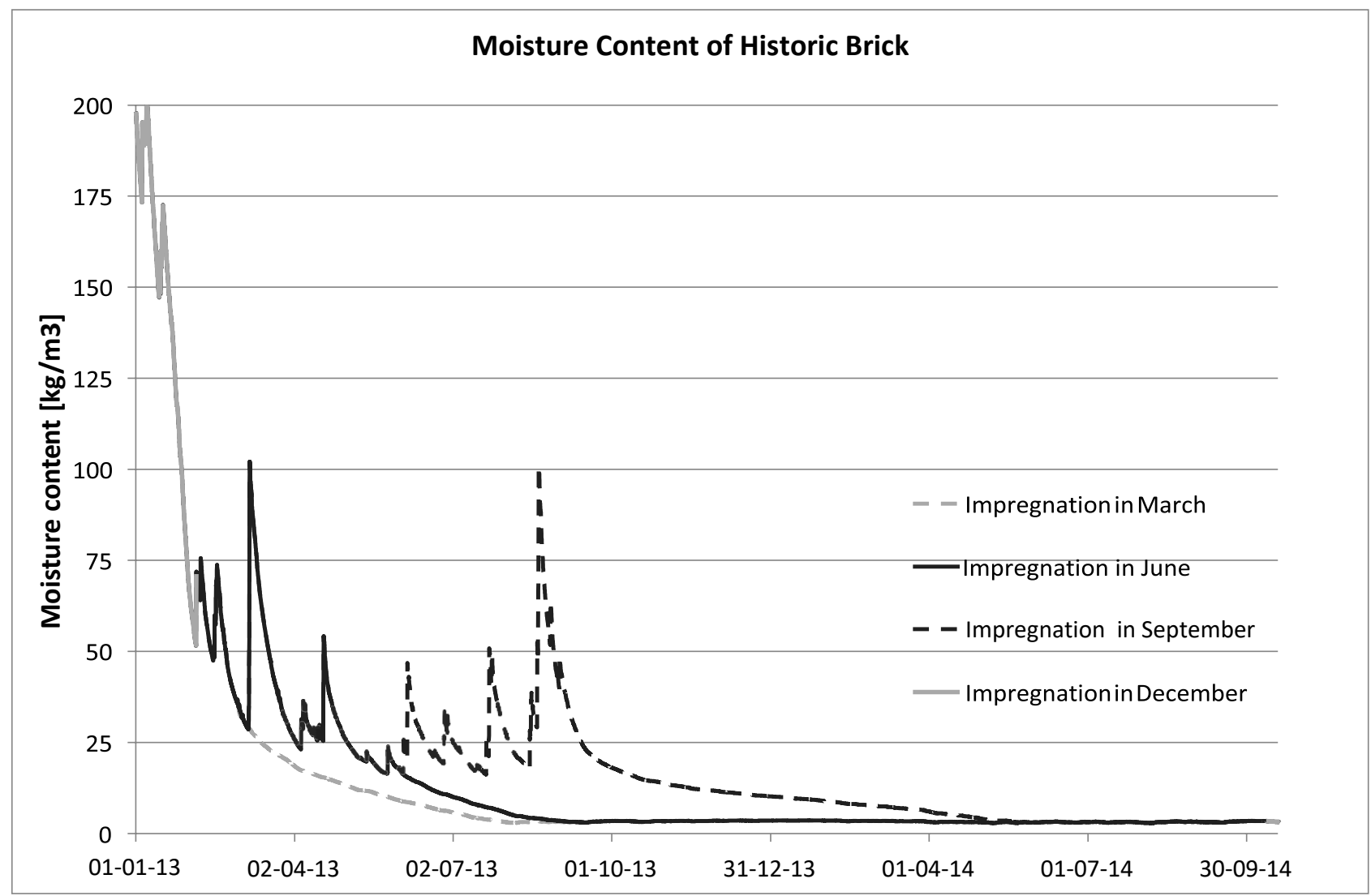

Figure 13. Average moisture content of the $228 \mathrm{~mm}$ historic brick wall for 4 different times for applying impregnation: March, June, September and December.

4 If impregnation is added together with internal insulation, the drying out looks a bit different but

5 still the wall is able to dry out regardless of the time of the year this took place. Figure 14 shows

6 relative humidity in the interface of the original wall and $50 \mathrm{~mm} \mathrm{CaSi}$ insulation. The results show

7 that adding insulation and impregnation in March and June gives the shortest drying out period in 8 the wall-insulation interface. 


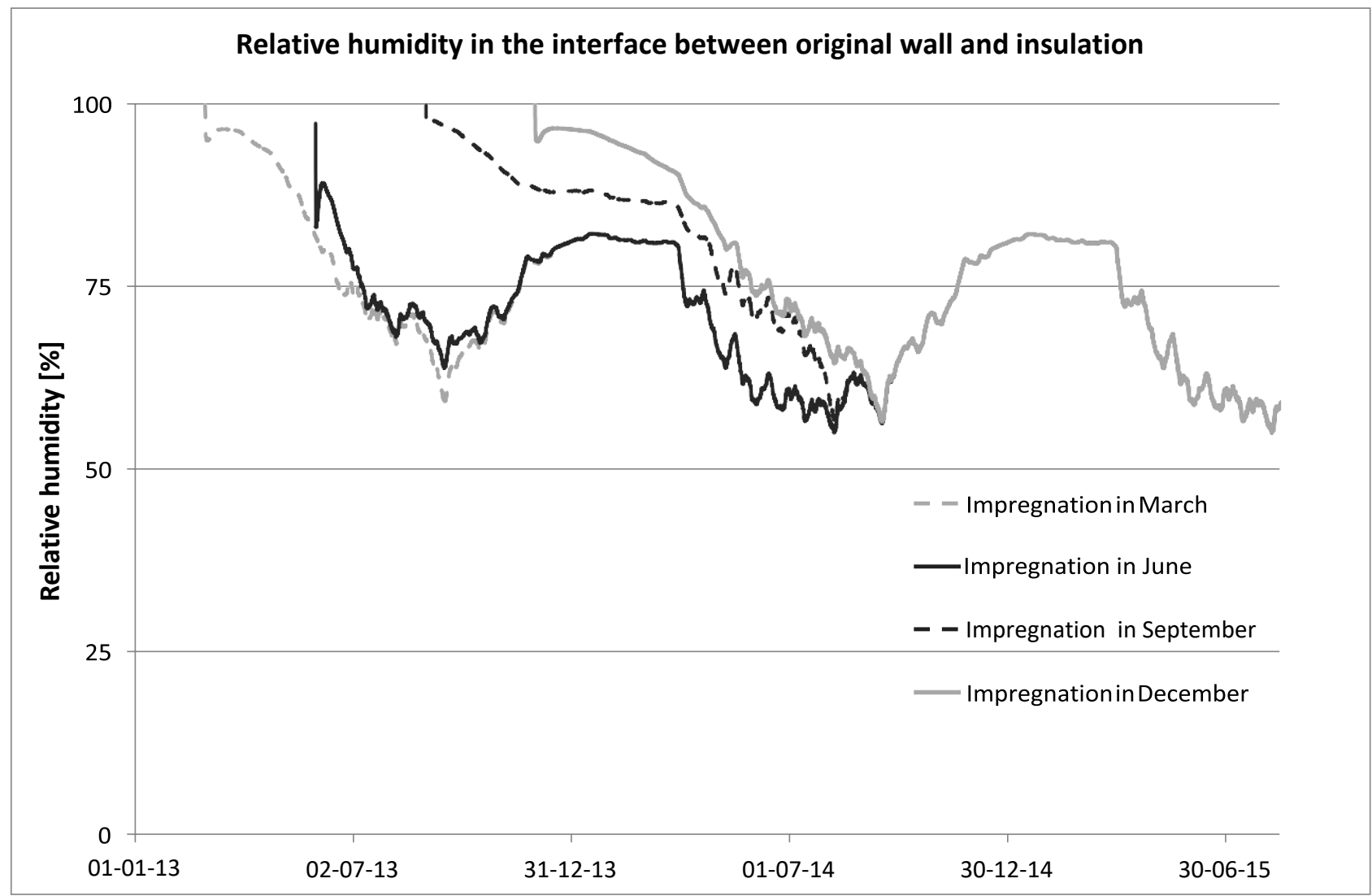

Figure 14: Relative humidity in the interface between $228 \mathrm{~mm}$ historic brick wall and $50 \mathrm{~mm}$ CaSi insulation for 4 different times for applying impregnation and insulation: March, June, September and December.

\subsection{Error sources}

The results of the present study depend highly on the assumptions and the chosen material properties and boundary conditions. In this study, the material properties are from the material database of the simulation tool and can therefore only be an assumption. While the properties of new building materials are more or less standardised, the properties of historic materials' can vary greatly. Consequently, the results will be less accurate. In the present study, "historic brick" has been chosen to account for the higher porosity that is generally occurring in older bricks. In this study, only 1D simulations were performed. This is appropriate for giving a first picture of the performance of several wall assemblies [32], but the reader must have in mind that 1D 
1 simulations are much less capable -and thereby less conclusive- than 2D and 3D simulations in

2 situations where two-dimensional or even three-dimensional effects exist. This applies for

3 example to embedded beam/joist ends and cracks. Wooden beam ends have not been included in

4 the calculations for the sake of simplicity; however, this should not affect the conclusions in this

5 study except that no information is available for wooden beam ends. The situation is different in

6 case of the simulated cracks. 1D simulations imply that intruding moisture can only move

7 horizontally, which is not the case in reality. Consequently, this fact weakens the conclusions

8 regarding the effect of cracks in the present study. However, a possible moisture distribution in

9 more than one direction means that the effect of cracks is probably overestimated in 1D

10 simulations compared to multidimensional simulations. But to get a real picture, 1D simulations

11 are not sufficient.

12 The boundary conditions have been chosen close to the actual case for most parameters, but for a

13 few parameters a worst case scenario was simulated.

14 Weather data for Lund has been used as an approximation of the one of Copenhagen, which is a 15 possible source of inaccuracy. However, real weather data from field monitoring would have been 16 even more reliable. The calculations of the possible "energy savings" due to insulation and 17 impregnation of the exterior wall are solely based on WUFI's calculation of heat flux through the 18 wall. It cannot be said whether the same savings would be achieved in experimental analysis of the energy performance or not, thus, the results of this study must be treated withcaution. 


\section{5. Conclusion}

2 This study showed that both capillary active insulation materials and façade impregnations can be used to improve the hygrothermal performance of historic facades. However, in areas with high precipitation (as it is the case in for example Denmark), capillary active or hydrophilic insulation may not be feasible without an additional protecting of the façade against driving rain, since there is high risk of moisture accumulation behind the insulation. This applies especially in cases when the wall is relatively thin (due to greater influence of the driving rain on the conditions close to the insulation) and when the insulation is very thick (due to the lower temperature of the wall behind the insulation); see Figure 11 for Mould Index depending on insulation thickness. Façade impregnations can be a solution when a driving rain protection by the construction itself for example by roof overhangs is not possible. If impregnation and insulation is added in the spring and summer time in Denmark, the drying out period is shortest.

Historical buildings will due to their ageing often have several cracks and damaged mortar joints resulting in water ingress and greater moisture and freezing problems behind the façade. To avoid these problems, existing cracks and damaged mortar joints must be repaired prior to the interior insulation and impregnation of the façade.

The scope of this study was to investigate the hygrothermal performance of retrofitting historical brick walls with so called capillary active insulation materials. These insulation systems are vapour open. However, vapour tight interior insulation systems may prove to perform better, especially in respect to the potential energy savings, but also in respect to moisture safety - if the façade is 21 impregnated - as also found in [33]. Further work should include demonstration tests under real life conditions and with assessment of the long-term performance. To reflect the heat and moisture behaviour of the whole building 
1 more accurate, it is necessary to use at least two-dimensional but ideally three-dimensional 2 simulations, where for example the effects on the vulnerable wooden beam ends, and also the 3 effect of cracks, i.e. water ingress to due rain leaks, are simulated more detailed. Finally, the 4 reduction of the uncertainties in the used input data, especially material data, should be met with $5 \quad$ e.g. probabilistic methods.

6 7 


\section{References}

1. European Commission, Directive 2010/31/EU of the European Parliament and of the Council of 19 May 2010 on the energy performance of buildings (recast). Official Journal of the European Union, L153, 2010;18:13-35.

2. Toman J, Vimmrova A, Cerny R. Long-term on-site assessment of hygrothermal performance of interior thermal insulation system without water vapour barrier. Energy Build 2009;41:51-5.

3. Gorse C, Highfield D. Upgrading the thermal performance of walls. Second ed., London \& New York: Spon Press; 2009, p. 60-87.

4. Künzel HM. Flexible vapor control solves moisture problems of building assemblies -Smart retarder to replace the conventional PE-Film. J Therm Envel Build Sci 1999;23:95-102.

5. Häupl P. Innendämmung von Aussenbauteilen. Bauphysik Kal 2010:147-86.

6. Häupl P, Jurk K, Petzold H. Inside thermal insulation for historical facades. Research in Building Physics: Proceedings of the 2nd International Conference on Building Physics Leuven, Belgium, 14-18 September 2003: p. 463-9.

7. Pavlik Z, Cerny R. Hygrothermal performance study of an innovative interior thermal insulation system. Appl Therm Eng 2009;29:1941-6.

8. Zach J, Korjenic A, Petránek V, Hroudová J, Bednar T. Performance evaluation and research of alternative thermal insulations based on sheep wool. Energy Build 2012;49:246-53.

9. Korjenic A, Petránek V, Zach J, Hroudová J. Development and performance evaluation of natural thermal-insulation materials composed of renewable resources. Energy Build 2011;43:2518-23.

10. Häupl P, Fechner H, Martin R, Neue J. Energetische Verbesserung der Bausubstanzmittels kapillaraktiver Innendämmung. Bauphysik 1999;21:145-54.

11. Grunewald J, Ruisinger U, Häupl P. The Rijksmuseum Amsterdam - Hygrothermal analysis and dimensioning of thermal insulation. Proc. 3rd International Building Physics/Science Conference, Montreal 2006: p. 345-52.

12. Vereecken $E$, Roels $S$. A comparison of the hygric performance of interior insulation systems: A hot box-cold box experiment. Energy Build 2014;80:37-44.

13. Vereecken $E$, Roels $S$. Capillary active interior insulation: do the advantages really offset potential disadvantages? Mater Struct 2015;48:3009-21.

14. Künzel HM. Simultaneous heat and moisture transport in building components. One-and two-dimensional calculation using simple parameters. Stuttgart: Fraunhofer-IRB-Verlag; 1995.

15. Künzel HM. Effect of interior and exterior insulation on the hygrothermal behaviour of exposed walls. Mater Struct 1998;31:99-103.

16. Couto S, Gonçalves TD, Lopes JMG. Drying of red ceramic brick. Effect of five silicone-based water-repellent treatments. Hydrophobe VI. 6th Int. Conf. on Water Repellent Treatment of Building Materials, Istituto Superiore per la Conservazione ed il Restauro (ISCR), Rome, Italy, 12-13 May, Aedificatio Publishers; 2011, p. 81-92.

17. Kaesler KH. The hidden defenders. Eur Coatings J 2006:36.

18. Roos M, König F, Stadtmüller S, Weyershausen B. Evolution of silicone based water repellents for modern building protection. Hydrophobe V. - 5th International Conference 
on Water Repellent Treatment of Building Materials, Freiburg: Aedificatio Publishers;2008, p. 3-16.

19. MacMullen J, Zhang Z, Rirsch E, Dhakal HN, Bennett N. Brick and mortar treatment by cream emulsion for improved water repellence and thermal insulation. Energy Build 2011;43:1560-5.

20. Rirsch E, Zhang Z. Energy saving from water repellents. Retrofit 2012, University of Salford, Manchester, 2012.

21. WTA Merkblatt 6-4-09/D: Innendämmung nach WTA I: Planungsleitfaden. 2010.

22. Van Hees RPJ. Facade treatments of historical buildings: Limiting the risks. In: M Koui, F Zezza \& P Koutsoukos (Eds.), Proceedings of the 8th International symposium on the conservation of monuments in the Mediterranean Basin. Athen: Technical Chamber of Greece: 2013, p. 53-60.

23. Worch A, Auras M. Innendämmung von einschaligem Ziegelmauerwerk. Hydrophobierung material- und denkmalgerecht? Bausubstanz 2012;3:56-61.

24. Fraunhofer IBP. WUFI Pro 2014 [software].

25. Vereecken E, Saelens D, Roels A. A comparison of different mould prediction models. Proc. Build. Simul., 2011.

26. Bjarløv S, Finken G, Odgaard T. Retrofit with interior insulation on solid masonry wallsin cool temperate climates - An evaluation of the influence of interior insulation materials on moisture condition in the building envelope. Energy Procedia 2015;78:1461-6.

27. Brandt E. Fugt i bygninger (SBi-anvisning 224) [Moisture in buildings (SBi guideline 224)]. Second ed., Hørsholm: Danish Building Research Institute, Aalborg University, 2013 [in Danish].

28. American Concrete Institute, editor. ACl 122R-02. Guide to Thermal Properties of Concrete and Masonry Systems. Farmington Hills, MI, 2002.

29. Spirgatis R, Engel J. Hydrophobierende Imprägnierung von Fassadenoberflächen. Schützen Erhalt 2010;3:11-5.

30. Krus M, Künzel HM. Untersuchungen zum Feuchteverhalten von Fassaden nach Hydrophobierungsmassnahmen. WTA Journal 2003;1:149-66.

31. Building regulations 2010 (BR10). Copenhagen: Danish Ministry of Economic and Business Affairs; 2010.

32. Dalgliesh WA, Cornick SM, Maref W, Mukhopadhyaya P. Hygrothermal performance of building envelopes: uses for 2D and 1D simulation. Proc., 10th Conf. on Building Science and Technology, Building Envelope Council Ottawa Region, Ontario. Ottawa: 2005, p. 3241.

33. Vereecken $E$, Van Gelder L, Janssen $H$, Roels S. Interior insulation for wall retrofitting -A probabilistic analysis of energy savings and hygrothermal risks. Energy Build 2015;89:23144. 